\title{
Teknologi E-commerce dan Pengalaman Konsumen
}

\section{E-commerce Technology and Customer Experience}

\author{
Dera Thorfiani ${ }^{1,}$, Senny Handayani Suarsa ${ }^{1}$, Bheben Oscar $^{2}$
}

1)Program Studi D4 Manajemen Perusahaan, Politeknik Pos Indonesia, Bandung, Indonesia

2)Program Studi D3 Manajemen Pemasaran, Politeknik Pos Indonesia, Bandung, Indonesia

*Corresponding Email: dthorfiani@poltekpos.ac.id

\begin{abstract}
Abstrak
Penelitian ini bertujuan mengetahui analisis deskriptif setiap variabel: e-commerce technology, variabel indepenent; customer experience, variabel dependent; dan e-commerce platform, variabel intervening kemudian selanjutnya dianalisis bagaimana pengaruh langsung maupun tidak langsung dari variabel teknologi $e$ commerce, terhadap variabel pengalaman konsumen, pada saat menggunakan platform e-commerce sebagai variable intervening. Metode yang digunakan adalah kuantitatif dan berdasarkan hasil pengolahan data analisis faktor dan Structural Equation Modeling (SEM), dengan menggunakan software SPSS 23 dan SMART-PLS didapatkan hasil: 1) variabel e-commerce technology secara tidak langsung berpengaruh secara positif dan signifikan terhadap customer experience pada saat menggunakan e-commerce platform, 2) variabel e-commerce technology berpengaruh langsung secara positif dan signifikan terhadap customer experience. Area pada penelitian ini masih terlalu sempit karena hanya mencakup Bandung Raya, dan kurang spesifik untuk penilaian platform e-commerce yang digunakan. Untuk penelitian yang akan datang cakupan penelitian dapat diperluas dan platform e-commerce yang digunakan dapat lebih spesifik pada platform tertentu sehingga didapatkan hasil yang lebih detail.
\end{abstract}

Kata Kunci: E-commerce, Teknologi E-commerce, E-commerce Platform, Pengalaman, Konsumen

\begin{abstract}
This study aims to determine the descriptive analysis of each variable: e-commerce technology, independent variables; customer experience, the dependent variable; and e-commerce platform; the intervening variables are then analyzed how the direct or indirect influence of the independent variables, e-commerce technology, on the dependent variable, consumer experience, when using the e-commerce platform as an intervening variable. The quantitative method is used in this study. Based on the results of factor analysis and Structural Equation Modeling (SEM) data processing, using SPSS 23 and SMART-PLS software, the results are: 1) e-commerce technology variables indirectly have a positive and significant effect on customer experience when accessing the e-commerce platform, 2) the e-commerce technology variable has a positive and significant direct effect on customer experience. The area in this study is still limited because it merely covers Bandung Raya and is not specific for the assessment of the e-commerce platform used. For future research, the scope of research can be expanded, and the e-commerce platform used can be more specific to certain platforms so that more detailed results can be obtained Keywords: E-commerce, E-commerce Technology, E-commerce Platform, Experience, Customer.
\end{abstract}

How to Cite: Thorfiani, D., Suarsa, S.H. \& Oscar, B. (2021). Teknologi E-commerce dan Pengalaman Konsumen. JKBM (Jurnal Konsep Bisnis dan Manajemen). 7 (2): 139-148 


\section{PENDAHULUAN}

Salah satu manafaat teknologi yang telah dirasakan adalah mendorong munculnya $e$ commerce (Maria \& Widayati, 2020). Menurut Laudon dan Traver (2016) e-commerce didefinisikan sebagai penggunaan internet, web, aplikasi seluler dan browser yang berjalan pada perangkat seluler untuk bertransaksi bisnis dan melibatkan pihak eksternal perusahaan seperti pemasok dan konsumen. Faktor utama munculnya e-commerce adalah adanya teknologi, yang menyebabkan perubahan traditional commerce menjadi e-commerce. Teknologi Informasi dan Komunikasi (TIK) menjadi salah satu kunci utama inovasi dan pertumbuhan e-commerce di negara maju dan berkembang (Amiri \& Woodside, 2017).

Infrastruktur TIK dan teknologi e-commerce dapat mempengaruhi pengalaman konsumen saat bertransaksi online. Teknologi meningkatkan interface dan konten pada platform untuk membuat konsumen loyal (Melati \& Dewi S.P, 2020). Walaupun jumlah pengguna internet di Indonesia masih sedikit dibandingkan jumlah rata-rata dunia (ITU, 2019), pertumbuhan pengguna $e$ commerce di Indonesia cukup besar dalam beberapa tahun terakhir (Katadata, 2019). Apalagi dengan adanya pandemi Covid-19, konsumen terpaksa bertransaksi online karena harus mengurangi kegiatan di luar rumah (Chandra et al., 2020).

Laudon \& Traver (2016) membagi teknologi e-commerce menjadi beberapa dimensi unik, ubiquity, tersedia di mana saja, global reach, di mana penjualan e-commerce lebih terjangkau secara global dibanding sebelumnya; universal standar, standar sama di seluruh dunia, biaya lebih murah, mudah, akurat dan mempermudah pertemuan pembeli dan penjual (Bakos, 1997; Banerjee \& Chakravarty, 2011); richness, kekayaan informasi yang mengacu pada kompleksitas pesan (Evans \& Wurster, 1999); interactivity, komunikasi dua arah; information density, kualitas informasi; personalization/ cus-tomization, teknologi AI dan Big Data digunakan untuk menampilkan interface terpersonalisasi pada $e$ commerce platform (Kumar \& Chaudhary, 2016; Tucker, 2008); dan Social technology: UserGenerated Content and Social Networks, memungkinkan pengguna membuat dan berbagi konten ke seluruh dunia dengan menggunakan media sosial. Konsep penyebaran pengalaman konsumen melalui media elektronik mengenai suatu barang dan jasa sebelumnya dikenal dengan "Electronic Word of Mouth Marketing". Menurut Suarsa (2020) eWOM memungkinkan konsumen berbagi informasi, berinteraksi antar konsumen, dan berpendapat menggunakan jejaring sosial.

Transaksi e-commerce membutuhkan server merchant e-commerce atau platform apli-kasi $e$ commerce dengan fitur lengkap dan dapat membuat konsumen nyaman bertransaksi daring. Fungsi dasar yang diperlukan untuk penjualan online: katalog online, keranjang belanja online, dan proses pembayaran (Kenneth C. Laudon dan Carol G.Traver, 2016). Situs web transaksional ini biasanya sangat sensitif terhadap kualitas pelayanan (Ghavamipoor et al., 2016). Pelanggan berharap mendapatkan pengalaman yang baik dan kualitas tinggi pada saat menggunakan layanan e-commerce tersebut. 
Selain itu, kemudahan pencarian dan pemilihan barang, dan kemudahan proses pembayaran juga dapat mempengaruhi perilaku konsumen. Perilaku konsumen didefiniskan sebagai semua kegiatan, tindakan, dan proses psikologis, yang mendorong konsumen sebelum proses pembelian, saat melakukan pembelian, menggunakan produk dan jasa yang dibeli, kegiatan mengevaluasi, dan pengalaman setelahnya (Kotler \& Keller, 2016; Solomon, 2018). Dalam perilaku konsumen, pengalaman konsumen adalah yang paling penting dan dapat ditemukan pada proses interaksi di titik temu antara penjual dan pembeli saat mengkonsumsi barang atau jasa (Srivastava \& Kaul, 2016).

Menurut Nasermoadeli et al. (2013), pengalaman konsumen dapat diukur melalui tiga dimensi: sensory experience, persepsi estetika dan sensorik tentang lingkungan belanja, atmosfer, produk dan layanan yang melibatkan indera manusia; emotional experience, suasana hati dan emosi yang berkembang saat proses berbelanja dan social experience, hubungan dengan orang lain, berdampak sosial dan dapat mempengaruhi pemikiran, perasaan dan aktivitas konsumen. Menurut Bilgihan et al. (2016) hal-hal yang mempengaruhi pengalaman konsumen saat berbelanja online meliputi: kemudahan mengakses dan menggunakan web, Hedonic and Utilitarian Features, kenyamanan, personalisasi, interaksi sosial, dan kompatibilitas pada berbagai perangkat. Penulis juga menyatakan bahwa terdapat hubungan signifikan antara social e-commerce serta pengaruhnya pada customer experience. Tujuan penelitian ini yaitu mengetahui bagaimana pengaruh e-commerce technology terhadap customer experience pada saat berbelanja melalui paltform e-commerce marketpalce. Paparan di atas dapat digambarkan pada kerangka pemikiran berikut ini:

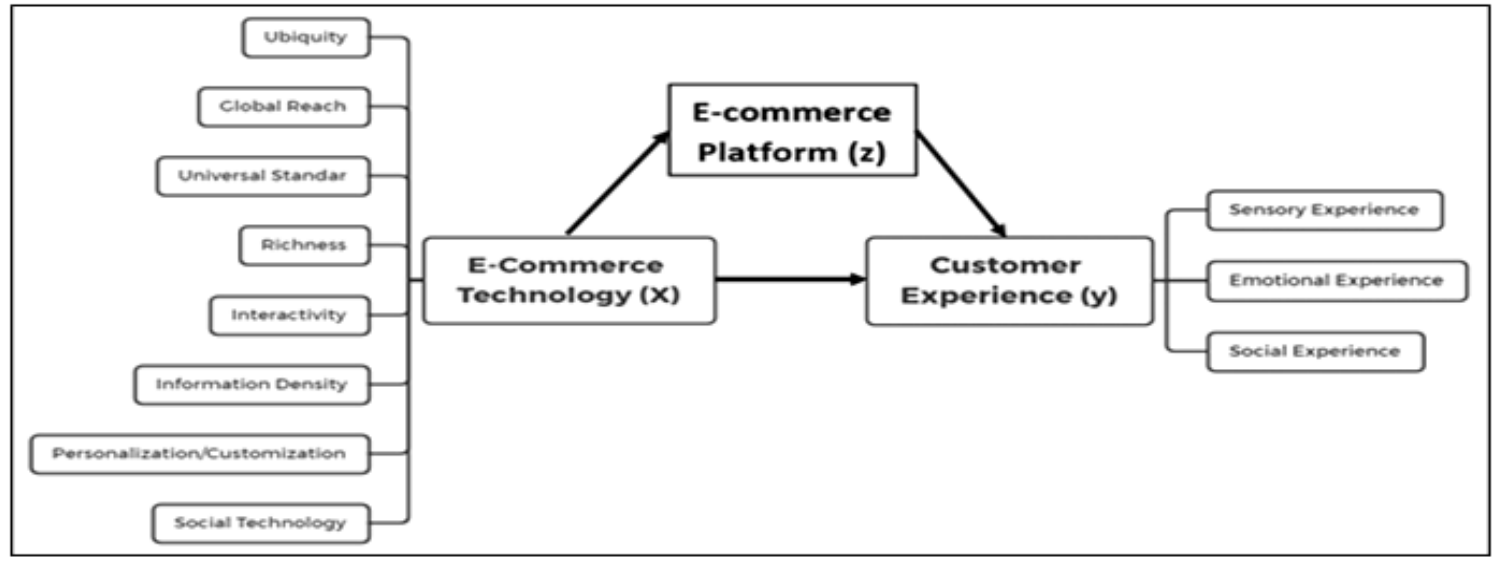

Gambar 1 Kerangka Pemikiran Sumber: Hasil Olahan Penulis, 2020

Penelitian ini fokus pada hubungan antara variabel e-commerce technology (x), customer experience (y), dan variebel penghubung, $e$ commerce platform (z). Hipotesis penelitian yang platform. diajukan yaitu:
H1: E-commerce technology secara tidak langsung berpengaruh positif dan signifikan terhadap customer experience saat menggunakan e-commerce 
H2: E-commerce technology secara tidak langsung tidak berpengaruh positif dan signifikan terhadap customer experience saat menggunakan e-commerce platform.

H3: E-commerce technology secara langsung berpengaruh positif dan signifikan terhadap customer experience

H4: E-commerce technology secara langsung tidak berpengaruh positif dan signifikan terhadap customer experience.

\section{METODE PENELITIAN}

Penelitian ini menggunakan metode deskriptif kuantitatif, yaitu metode penelitian yang berlandaskan pada filsafat positifisme, digunakan untuk meneliti populasi atau sampel tertentu (Sugiyono, 2017). Populasi pada penelitian adalah pengguna plaform e-commerce di Bandung Raya: Kota Bandung, Kota Cimahi, Kab. Bandung Barat dan Kab. Bandung, dengan jumlah populasi tidak diketahui. Jumlah sampel mengacu pada 10 times rule, dengan ketentuan PLS-SEM berdasarkan: (1) 10 kali jumlah indikator formatif terbesar yang digunakan untuk mengukur satu konstruk atau, (2) 10 kali jumlah terbesar dari jalur struktural yang diarahkan pada konstruk tertentu dalam model struktural (Hair Jr. et al., 2016). Artinya, sampel minimum adalah
10 kali jumlah panah maksimum yang menunjuk pada variabel laten di mana saja dalam model jalur PLS dengan besar sampel minimum 10 kali jumlah variabel independen dari Ordinary Least Square (OLS) paling kompleks dalam model pengukuran struktural atau formatif. Minimal jumlah sampel pada penelitian ini $3 \times 10$ yaitu 30 sampel. Untuk memperkuat hasil, jumlahnya ditambah menjadi 100 responden, yaitu para konsumen e-commerce di Bandung Raya. Pengumpulan data menggunakan kuesioner dengan skala semantik; digunakan sebagai ukuran tidak langsung dari perasaan seseorang tentang suatu hal (Silalahi, 2017:35), dan studi pustaka. Distribusi kuesioner menggunakan metode $e$ questionnaire yang mempunyai kelebihan pendistribusian yang mudah dan cepat (Sekaran \& Bougie, 2016). Analisis faktor digunakan untuk mencari hubungan (interrelationship) antara variabel bebas: e-commerce technology, kemudian dibuat kumpulan variabel yang lebih sedikit dari sebelumnya. Selanjutnya diuji dengan Structural Equation Model (SEM) dan aplikasi Smart PLS untuk menganalisis hubungan dan pengaruh antara tiap variabel (Silalahi, 2017:568). Hasil model pengukuran dianalisis dengan memperhatikan rule of thumb berikut ini:

Tabel 1 Ringkasan Rule of Thumb Evaluasi Model Pengukuran Reflektif

\begin{tabular}{|c|c|c|}
\hline Validity \& Reliability & Parameters & Rule of Thumb \\
\hline \multirow{2}{*}{ Convergent Validity } & Indicator's Outer Loading & $>0,78$ \\
\hline & Average Variance Extracted & $>0,50$ \\
\hline \multirow{2}{*}{ Discriminant Validity } & Cross Loading & $\begin{array}{c}\text { Outer loading pada suatu konstruk > semua nilai cross } \\
\text { loading dengan konstruk yang lain }\end{array}$ \\
\hline & $\begin{array}{l}\text { Akar Kuadrat AVE dan korelasi } \\
\text { antar konstruk laten }\end{array}$ & $\begin{array}{l}\text { Kuadrat korelasi antar konstruk laten < AVE masing- } \\
\text { masing konstruk yang berhubungan }\end{array}$ \\
\hline \multirow{2}{*}{$\begin{array}{c}\text { Internal Consistency } \\
\text { Realibility }\end{array}$} & Cronbrach's Alpha & $\begin{array}{c}>0,70 \text { untuk confirmatory research, dan }>0,60 \text { masih } \\
\text { dapat diterima untuk exploratory research }\end{array}$ \\
\hline & Composite Reliability & $\begin{array}{l}>0,708 \text { untuk confirmatory research, dan } 0,60-0,70 \\
\text { masih dapat diterima untuk exploratory research }\end{array}$ \\
\hline
\end{tabular}

Sumber: (Astuty, 2018; Hair Jr. et al., 2016) 
Sedangkan untuk penilaian hasil model struktural evaluasi model struktural berikut :

Tabel 2 Ringkasan Rule of Thumb Evaluasi Model Pengukuran Reflektif

\begin{tabular}{cc}
\hline Criterion & Rule of Thumb \\
\hline \multirow{2}{*}{-Square } & $0,67,0,33$, dan 0,19 menunjukkan model kuat, moderat, dan lemah \\
\cline { 2 - 2 } & $0,75,0,50$, dan 0,25 menunjukkan model kuat, moderat, dan lemah \\
\hline Effect Size $f^{2}$ & $0,02,0,15$, dan 0,35 (kecil, menengah, dan besar) \\
\hline \multirow{2}{*}{$Q^{2}$ predictive relevance } & $\mathrm{Q}^{2}>0$, model mempunyai predictive relevance \\
\hline$q^{2}$ predictive relevance & $\mathrm{Q}^{2}<0$, model kurang memiliki predictive relevance \\
\hline \multirow{2}{*}{ Significance (two-tailed) } & $0,02,0,15$, dan 0,35 (lemah, moderate, dan kuat) \\
\cline { 2 - 2 } & $t$-value $1.65($ significance level $=10 \%)$ \\
\hline
\end{tabular}

Sumber: (Astuty, 2018; Hair et al. 2016)

\section{HASIL DAN PEMBAHASAN}

Berdasarkan hasil kuesioner, dari 170 responden hanya 100 yang memenuhi kriteria: pernah bertransaksi e-commerce, pernah membeli barang dari luar negeri secara $e$ commerce dan berdomisili di Bandung Raya. 70 lainnya tidak memenuhi salah satu atau lebih kriteria responden tersebut. Berikut profil responden berdasarkan hasil kuesioner:

Tabel 3 Karakteristik Responden

\begin{tabular}{ll}
\hline \multicolumn{1}{c}{ Karakteristik } & Persentase \\
\hline Pekerjaan & $20,8 \%$ \\
\hline Profesional & $36,6 \%$ \\
\hline Karyawan & $19,8 \%$ \\
\hline Pelajar & $22,8 \%$ \\
\hline Lainnya & $19 \%$ \\
\hline Umur & $11 \%$ \\
\hline$<22$ tahun & $37 \%$ \\
\hline $22-27$ tahun & $27 \%$ \\
\hline $28-35$ tahun & $6 \%$ \\
\hline $36-45$ tahun & $43 \%$ \\
\hline$>45$ tahun & $32 \%$ \\
\hline Domisili & $16 \%$ \\
\hline Kota Bnadung & $9 \%$ \\
\hline Kabupaten Bandung Barat & \\
\hline Kota Cimahi & $46 \%$ \\
\hline Kabupaten Bandung & $54 \%$ \\
\hline Jenis Kelamin & $95 \%$ \\
\hline Wanita & $41 \%$ \\
\hline Pria & $51 \%$ \\
\hline Platform yang sering dipakai & $55 \%$ \\
\hline Shopee & \\
\hline Lazada & \\
\hline Bukalapak & \\
\hline Tokopedia & \\
\hline
\end{tabular}

Analisis faktor dilakukan dengan menguji variabel menggunakan metode Bartlett Test of Sphericity dan pengukuran MSA (Measure of Sampling Adequacy). Pada tahap ini dilakukan penyaringan variabel agar memenuhi syarat untuk dianalisis. Berikut hasil penghitungan:

Tabel 4 KMO and Bartlett's Test Kaiser-Meyer-Olkin Measure of Sampling Adequacy.

,838

\begin{tabular}{lcc}
\hline \multirow{2}{*}{$\begin{array}{l}\text { Bartlett's Test } \\
\text { of Sphericity }\end{array}$} & Approx. Chi-Square & 2.703 .188 \\
\cline { 2 - 3 } & $d f$ & 741 \\
\hline
\end{tabular}

Sumber: Hasil olahan penulis Oktober 2020

Nilai $K M O$ sudah $>0,5$ dan signifikansi $<0,05$ maka dimensi tersebut dapat dianalisis dengan analisis faktor. Berikutnya nilai MSA pada setiap indikator diukur dengan kriteria: $M S A=1$ variabel dapat diprediksi tanpa kesalahan oleh variabel lain; $M S A>0,5$ variabel masih bisa diprediksi dan dianalisis lebih lanjut; $M S A<0,5$ variabel tidak bisa diprediksi dan dianalisis, maka dikeluarkan dari penghitungan (Santoso, 2017).

Tabel 5 Hasil Penghitungan Factoring dan Rotasi

\begin{tabular}{lllll}
\hline & \multicolumn{4}{c}{ Component } \\
\cline { 2 - 5 } & $\begin{array}{c}\text { Ease to Access } \\
\text { Information }\end{array}$ & $\begin{array}{c}\text { Ease of } \\
\text { Inansaction }\end{array}$ & Tertinggi \\
\hline XA1 & $-0,04$ & 0,281 & 0,662 & 0,662 \\
\hline XA2 & 0,258 & $-0,001$ & 0,672 & 0,672 \\
\hline XA3 & 0,16 & 0,033 & 0,189 & 0,189 \\
\hline XB1 & 0,26 & $-0,082$ & 0,338 & 0,338 \\
\hline
\end{tabular}


Thorfiani, D., Suarsa, S.H. \& Oscar, B. (2021). Teknologi E-commerce dan Pengalaman Konsumen

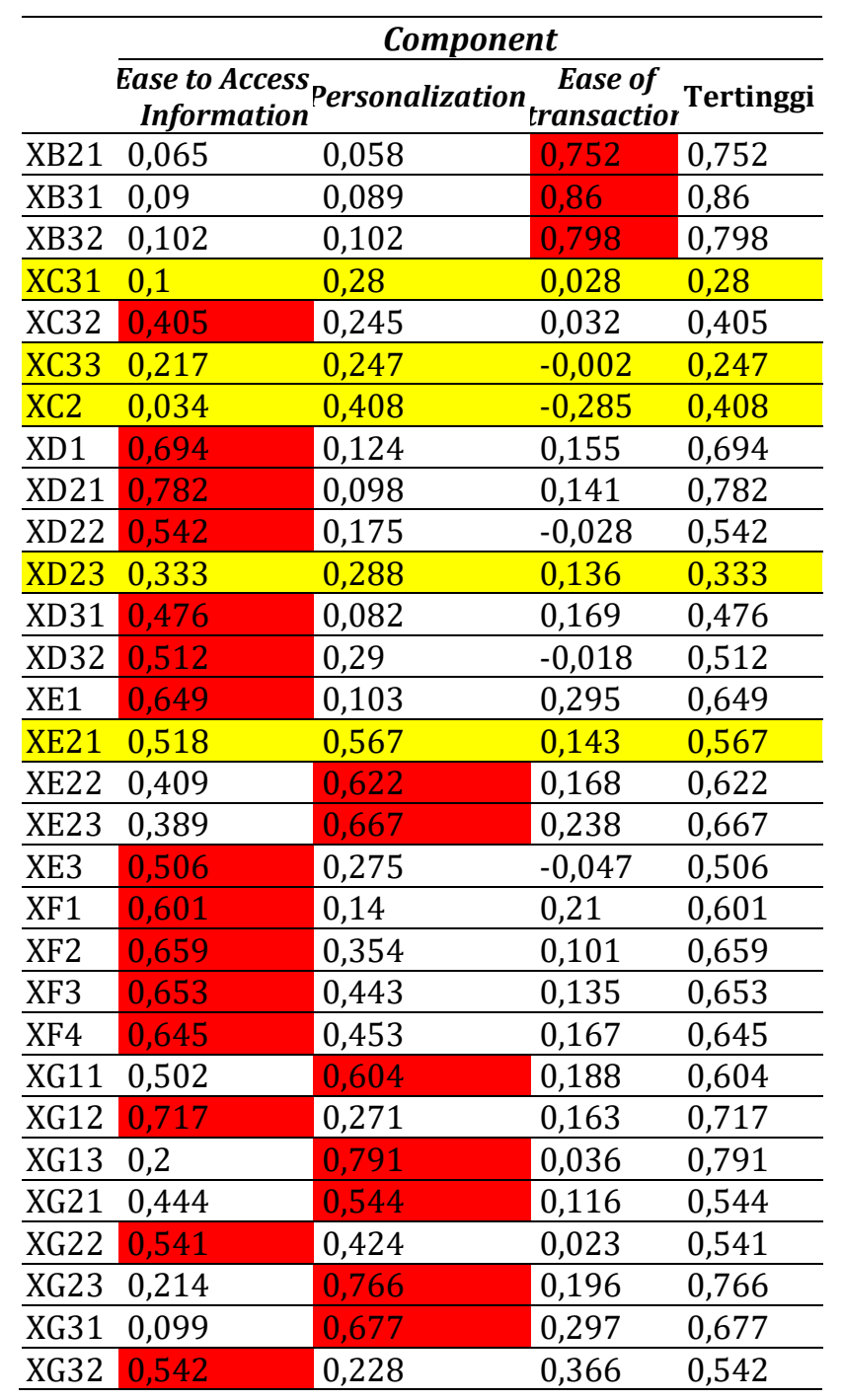

\begin{tabular}{lllll}
\hline & \multicolumn{4}{c}{ Component } \\
\cline { 2 - 5 } & $\begin{array}{c}\text { Ease to Access } \\
\text { Information }\end{array}$ & Eersonalization & \multicolumn{1}{c}{$\begin{array}{c}\text { Ease of } \\
\text { transactior }\end{array}$} & Tertinggi \\
\hline XG4 & 0,12 & 0,693 & $-0,116$ & 0,693 \\
\hline XG5 & 0,573 & 0,363 & 0,224 & 0,573 \\
\hline XH1 & 0,396 & 0,76 & 0,04 & 0,76 \\
\hline XH2 & 0,56 & 0,56 & 0,158 & 0,56 \\
\hline XH3 & 0,709 & 0,264 & 0,028 & 0,709 \\
\hline
\end{tabular}

Sumber : Hasil Olahan Penulis, 2020

Berdasarkan hasil olahan data analisis faktor dengan SPSS 23, dari 39 pertanyaan pada variabel e-commerce technology diekstraksi hingga terbentuk tiga faktor, lalu dirotasi untuk memperkuat korelasi tiap faktor yang terbentuk sehingga dihasilkan kelompok komponen seperti tabel di atas. Selanjutnya, factor loading yang nilainya $<0,5$ dihilangkan, yaitu: XA3, XB, XC31, XC33, XC2, XD23, XE21, dan XH2. Analisis SEM menggunakan software SMART PLS. Pada perhitungan pertama nilai AVE masih kurang dari 0,500, Oleh karena itu harus dilakukan perhitungan ulang yang kemudian didapatkan gambar model berikut:

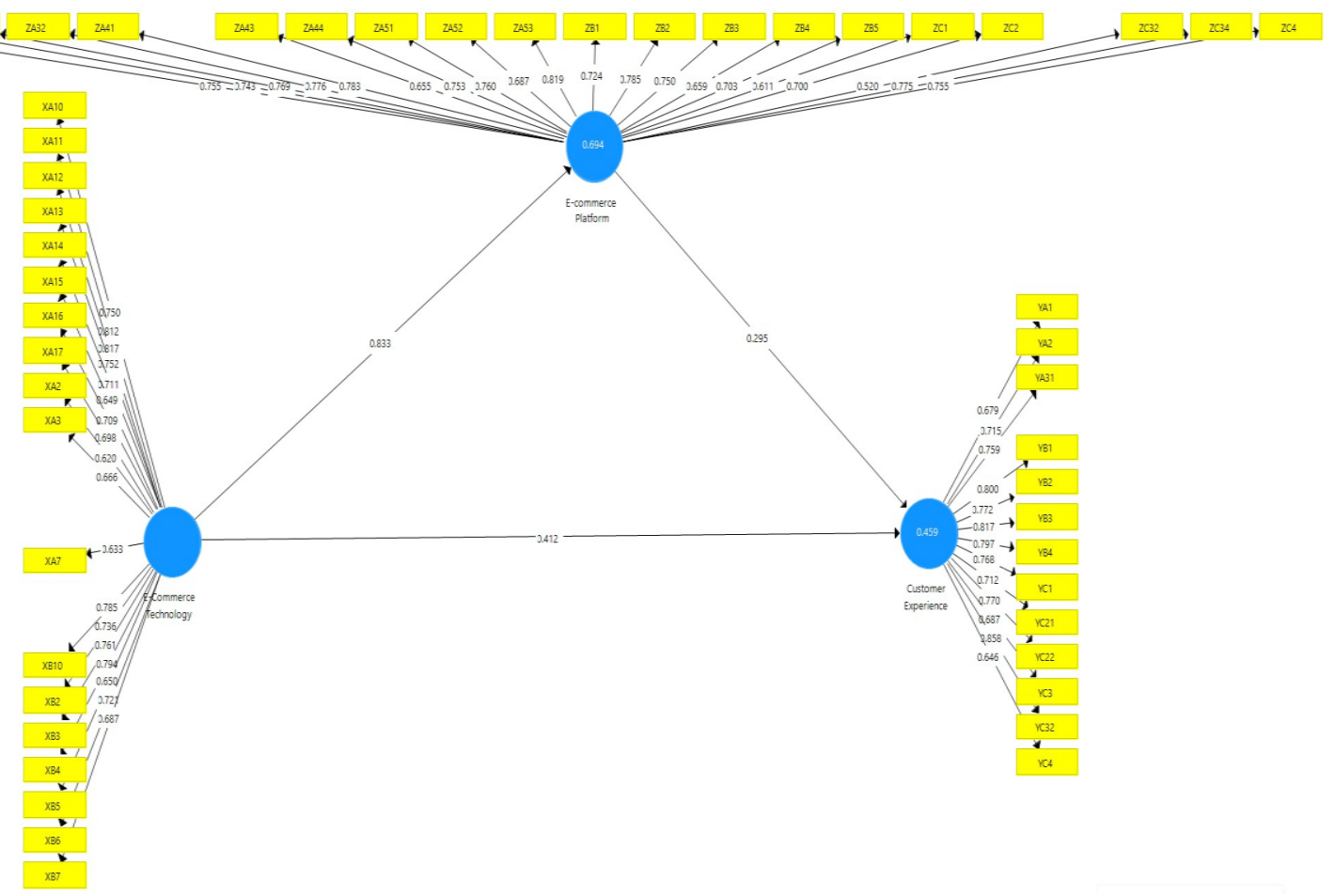

Gambar 2 Hasil Pengolahan Full Model Revisi 
Akhirnya, setelah factor loading dihilang- dan nilai cronbachs's alpha $>0,700$ yang dapat dikan dan dihitung ulang, didapatkan AVE $>0,500$ lihat pada tabel berikut:

Tabel 6 Average Variance Extracted Full Model Revisi

\begin{tabular}{lcccc}
\hline & Cronbach's Alpha & Rho_A & Composite Realibility & Average Variance Extracted (AVE) \\
\hline Customer Experience & 0,936 & 0,942 & 0,945 & 0,569 \\
\hline E-commerce Technology & 0,945 & 0,949 & 0,951 & 0,521 \\
\hline E-commerce Platform & 0,952 & 0,955 & 0,957 & 0,529 \\
\hline
\end{tabular}

Hal ini berarti data tersebut sudah dapat dipakai menghitung hubungan dan pengaruh dari setiap variabel pada penelitian ini yaitu variabel e-commerce technology, e-commerce platform dan customer experience karena sudah valid dan gai berikut:

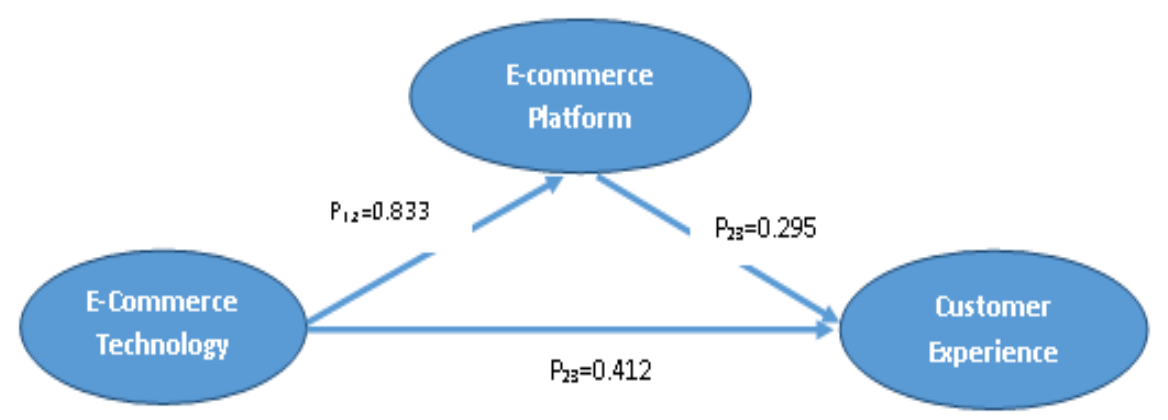

Gambar 3 Substruktur Model

Sumber : Hasil Pengolahan Penulis, 2020

Tabel 7 Mean, Standard Deviation, T Statistics, dan P Values

\begin{tabular}{lccccc|}
\hline & $\begin{array}{c}\text { Original } \\
\text { Sample } \\
(\boldsymbol{O})\end{array}$ & $\begin{array}{c}\text { Sample } \\
\text { Mean } \\
(\boldsymbol{M})\end{array}$ & $\begin{array}{c}\text { Standard } \\
\text { Deviation } \\
\text { (STDEV) }\end{array}$ & $\begin{array}{c}\text { T Statistics } \\
\text { (O/STEDV) }\end{array}$ & P Values \\
\hline E-commerce Technology $->$ Customer Experience & 0,412 & 0,432 & 0,133 & 3,093 & 0,002 \\
\hline E-commerce Technology $->$ E-commerce Platform & 0,833 & 0,838 & 0,031 & 26,520 & 0,000 \\
\hline E-commerce Platform $->$ Customer Experience & 0,295 & 0,291 & 0,143 & 2,68 & 0,039 \\
\hline
\end{tabular}

Tabel 8 Pengaruh Langsung antar Variabel

\begin{tabular}{lccc}
\hline & Customer Experience & E-commerce Technology & E-Commerce Platform \\
\hline Customer Experience & & \\
\hline E-commerce Technology & 0,412 & 0,833 \\
\hline E-commerce Platform & 0,295 & \\
\hline
\end{tabular}

Tabel 9 Pengaruh tidak Langsung antar Variabel Customer Experience E-commerce Technology E-commerce Platform

Customer Experience

E-commerce Technology 0,426

E-commerce Platform

Tabel 10 Pengaruh Total antar Variabel

Customer Experience Customer Experience E-commerce Technology E-commerce Platform 
Hasil uji terhadap struktural full model revisi menunjukkan bahwa:

a. Variabel e-commerce technology berpengaruh langsung pada variabel customer experience, dibuktikan dengan nilai Tstat 3,093 (>1,650) dan signifikansi $p$-value $0,002(<0,05)$ artinya variabel e-commerce technology mampu memunculkan variabel customer experience sebesar $41,2 \%$.

b. Variabel e-commerce technology berpengaruh langsung pada variabel e-commerce platform, dengan nilai $T$-stat 26,520 $(>1,650)$ dan $p$ value $0,000 \quad(<0,05)$ artinya variabel $e$ commerce technology secara langsung mampu memunculkan e-commerce platform sebesar $83,3 \%$.

c. Variabel e-commerce platform berpengaruh langsung terhadap customer experience, nilai T-stat 2,068 (>1,650) dengan p-value 0,039 $(<0,05)$ artinya variabel e-commerce platform secara langsung mampu memunculkan customer experience sebesar 29,5\%.

d. Sedangkan untuk pengaruh tidak langsung, variabel e-commerce technology mampu mempengaruhi munculnya customer experience. Saat menggunakan e-commerce platform sebagai mediator bagi e-commerce technology untuk memunculkan customer experience memberikan pengaruh positif yang signifikan dengan total pengaruh $\rho_{12}$ dan $\rho_{23}\left(\rho_{12}{ }^{*} \rho_{23}=\right.$ $0,833 * 0,295$ ) sebesar $24,6 \%$. Sedangkan total effect dapat dikalkulasika: $\rho_{12}+\rho_{12} * \rho_{23}=$ $0,833+0,423 * 0,295=0,958$.

e. Pengaruh total e-commerce technology terhadap customer experience adalah 0,658 merupa- kan total pengaruh langsung 0,412 ditambah pengaruh tidak langsung 0,246. Hal ini berarti bahwa variabel e-commerce technology memberikan total pengaruh $65,8 \%$ terhadap variabel customer experience. Sedangkan total pengaruh dari variabel e-commerce technology ke variabel e-commerce platform dan variabel e-commerce platform ke customer experience besarnya sama dengan pengaruh langsung: 0,833 dan 0,295 atau 83.3\% dan 29.5\%.

Berdasarkan uji kekuatan model struktural didapatkan hasil sebagai berikut:

a. Menurut (Hair Jr. et al., 2016) nilai $\mathrm{R}^{2} 0,459$ dan 0,691 menunjukkan besar pengaruh model berada pada kategori moderat. Besar pengaruh e-commerce technology dan $e$ commerce platform pada variabel customer experience berdasarkan R adalah 44,8\%, sedangkan variabel e-commerce technology pada e-commerce platform adalah 69,1\%. Dengan demikian variasi pada variabel customer experience dapat dijelaskan oleh $e$ commerce technology dan e-commerce platform sebesar $69.1 \%$.

Tabel 11 Nilai $R$ Square

\begin{tabular}{lcc}
\hline & R. Square & $\begin{array}{l}\text { R Square } \\
\text { Adjusted }\end{array}$ \\
\hline $\begin{array}{l}\text { Customer } \\
\text { Experience }\end{array}$ & 0.459 & 0.448 \\
\hline $\begin{array}{l}\text { E-commerce } \\
\text { Platform }\end{array}$ & 0.694 & 0.691 \\
\hline
\end{tabular}

b. Nilai effect size pada model struktural $f^{2}=0,096$, berarti prediktor variabel e-commerce technology memiliki kekuatan kecil memprediksi munculnya customer experience, e-commerce platform juga memiliki kekuatan kecil memprediksi customer experience dengan nilai 
$f^{2}=0,049$, sedangkan variabel e-commerce technology memiliki kekuatan dalam kategori sedang memprediksi variabel e-commerce platform. Hal ini sesuai dengan teori Hair Jr. et al., (2016) yang mengatakan bahwa jika nilai effect size $f^{2}$ dari rule of thumb(inner model) dinyatakan kecil $=0,02$, sedang $=0,15$, dan besar $=0,35$

Tabel 12 Nilai $F$ Square

\begin{tabular}{lccc}
\hline & $\begin{array}{c}\text { Customer } \\
\text { Experience }\end{array}$ & $\begin{array}{c}\text { E-commerce } \\
\text { Technology }\end{array}$ & $\begin{array}{c}\text { E-commerce } \\
\text { Platform }\end{array}$ \\
\hline Customer Experience & & & \\
\hline E-commerce Technology & 0,096 & & $\mathbf{2 . 2 6 7}$ \\
\hline E-commerce Platform & 0,049 & & \\
\hline
\end{tabular}

Berdasarkan hasil analisis full model struktural (inner model) jawaban hipotesis yang diajukan dalam penelitian ini membuktikan bahwa terdapat pengaruh positif dan signifikan antara variabel e-commerce technology terhadap tingkat customer experience dengan mediasi e-commerce platform yakni sebesar $24,6 \%$ (nilai path coefficient sebesar 0,246). Hal ini berarti bahwa variabel e-commerce platform dapat menjadi mediasi untuk e-commerce technology dan customer experience, akan tetapi nilai pengaruhnya menjadi lebih kecil dibandingkan pengaruh langsung dari variabel e-commerce technology ke customer experience yaitu 41.2\%. Apabila dilihat dari signifikansi pengaruh tersebut masih dalam kategori signifikan karena nilai $P$ value $<0.05$

Berdasarkan hasil di atas disimpulkan bahwa $\mathrm{H}_{1}$ diterima dan $\mathrm{H}_{2}$ ditolak, artinya e-commerce technology secara tidak langsung berpengaruh positif dan signifikan terhadap customer experience pada saat menggunakan e-commerce platform.

Berikutnya, variabel e-commerce technology berpengaruh secara langsung terhadap variabel customer experience. Hal ini dibuktikan dengan nilai signifikansi $p$-value $0,002(<0,05)$ artinya, variabel e-commerce technology mampu me- munculkan variabel customer experience 41,2\% secara positif dan signifikan. Maka dapat disimpulkan bahwa $\mathrm{H}_{3}$ diterima dan $\mathrm{H}_{4}$ ditolak, artinya E-commerce technology secara langsung berpengaruh positif dan signifikan terhapadap customer experience.

\section{SIMPULAN}

Berdasarkan analisis pada penelitian " $E$ commerce Technology dan Customer Experience" yang telah dilakukan, dapat disimpulkan variabel e-commerce technology berpengaruh tidak langsung secara positif dan signifikan terhadap customer experience pada saat menggunakan $e$ commerce platform. Variabel e-commerce technology berpengaruh langsung secara positif dan signifikan terhadap customer experience.

\section{UCAPAN TERIMAKASIH}

Penulis mengucapkan terimakasih kepada Politeknik Pos Indonesia selaku pemberi dana pada penelitian ini.

\section{DAFTAR PUSTAKA}

Amiri, S., \& Woodside, J. M. (2017). Emerging markets: the impact of ICT on the economy and society. Digital Policy, Regulation and Governance, 19(5): 383-396.

Astuty, E. (2018). Soft Innovation Sebagai Strategi Peningkatan Kinerja Industri Kreatif Fesyen. Universitasi Pendidikan Indonesia. 
Bakos, J. Y. (1997). Reducing buyer search costs: Implications for electronic marketplaces. Management Science, 43(12): 1676-1692.

Banerjee, S., \& Chakravarty, A. (2011). Price Setting and Price Discovery Strategies with a Mix of Frequent and Infrequent Internet Users. SSRN Electronic Journal.

Bilgihan, A., Kandampully, J. A., \& Zhang, T. (Christina). (2016). Towards a unified customer experience in online shopping environments: antecedents and outcomes. International Journal of Quality and Service Sciences Article, 8(1).

Chandra, A. R., Wimeina, Y., \& Khairat, A. (2020). Penggunaan Media Sosial untuk Berbelanja Online Saat Pandemi Covid-19. Jurnal Konsep Bisnis Dan Manajemen, 7(1): 58-71.

Evans, P., \& Wurster, T. S. (1999). Getting real about virtual commerce. Harvard Business Review, $77(6)$.

Ghavamipoor, H., Golpayegani, S. A. H., \& Shahpasand, M. (2016). A QoS Sensitive Model for e-Commerce Customer Behavior. Journal of Research in Interactive Marketing, 11(4): 380-397.

Hair Jr., J. F., Hulth, T. M., Ringle, C. M., \& Sarstedt, M. (2016). A Primer on Partial Least Squares Structural Equation Modeling (2nd editio). SAGE Publication,Inc.

ITU. (2019). Number of Internet Users 2005-2019. https://www.itu.int/en/ITU-

D/Statistics/Pages/stat/default.aspx

Katadata. (2019). Tren Pengguna E-Commerce Terus Tumbuh. Databoks. https://databoks.katadata.co.id/datapublish/201 9/10/10/tren-pengguna-e-commerce-20172023\#

Kenneth C. Laudon dan Carol G.Traver. (2016). E commerce. business. technology. society. (12th Edition). Pearson Education Limited.

Kotler, P., \& Keller, K. L. (2016). Marketing Management (S. Wall (ed.); 16e ed.). Pearson Education Limited.
Kumar, S., \& Chaudhary, S. (2016). Investigating the Determinants of Service Quality: A Study of ERetailing. Srusti Management Review, IX(1, January-June), 37-45.

Maria, N. S. B., \& Widayati, T. (2020). Dampak Perkembangan Ekonomi Digital terhadap Perilaku Pengguna Media Sosial dalam Melakukan Transaksi Ekonomi. Jurnal Konsep Bisnis Dan Manajemen, 6(2): 234-239.

Melati, K. R., \& Dewi S.P, N. K. (2020). Integrated ECommerce Ecosystem in China and Indonesia's Giant Market. 423(Imc 2019): 251-269.

Nasermoadeli, A., Ling, K. C., \& Maghnati, F. (2013). Evaluating the Impacts of Customer Experience on Purchase Intention. International Journal of Business and Management, 8(6).

Santoso, S., (2017). Statistik multivariat dengan SPSS. Jakarta: Elex Media Komputindo.

Sekaran, U., \& Bougie, R. (2016). Research Methods for Business (Seventh Ed). Wiley.

Silalahi, U., (2017). Metode penelitian sosial kuantitatif. Bandung: Refika Aditama.

Solomon, M. R. (2018). Consumer Behavior. Buying, Having, and Being (S. Wall (ed.); Twelfth Ed). Pearson Education Limited.

Srivastava, M., \& Kaul, D. (2016). Exploring the link between customer experience-loyalty-consumer spend. Journal of Retailing and Consumer Services, 31: 277-286.

Suarsa, S. H. (2020). Pengaruh Electronic Word of Mouth (Ewom) Pada Online Travel Agent (Ota) Traveloka Terhadap Keputusan Menginap Di Topas Galeria Hotel, Bandung. Eqien: Jurnal Ekonomi Dan Bisnis, 7(1): 50-56.

Sugiyono, P. D. (2017). Metode Penelitian Kombinasi (Mixed Methods). ALFABETA, cv.

Tucker, S. P. (2008). E-commerce standard user interface: An E-menu system. In Industrial Management \& Data Systems (Vol. 108, Issue 8: 1009-1028). 